\title{
Novel anamorphic mite-associated fungi belonging to the Ustilaginomycetes: Meira geulakonigii gen. nov., sp. nov., Meira argovae sp. nov. and Acaromyces ingoldii gen. nov., sp. nov.
}

Correspondence

Teun Boekhout

boekhout@cbs.knaw.nl

\author{
Teun Boekhout, ${ }^{1}$ Bart Theelen, ${ }^{1}$ Jos Houbraken, ${ }^{1}$ Vincent Robert, ${ }^{1}$ \\ Gloria Scorzetti, ${ }^{2}$ Aviva Gafni, ${ }^{3}$ Uri Gerson ${ }^{3}$ and Abraham Sztejnberg ${ }^{4}$ \\ ${ }^{1}$ Centraalbureau voor Schimmelcultures, Uppsalalaan 8, 3584 CT Utrecht, The Netherlands \\ ${ }^{2}$ Rosenstiel School of Marine and Atmospheric Sciences, 4600 Rickenbacker Causeway, \\ Key Biscayne, FL 33149, USA \\ ${ }^{3,4}$ Departments of Entomology ${ }^{3}$ and Plant Pathology and Microbiology ${ }^{4}$, Faculty of Agricultural, \\ Food and Environmental Sciences, PO Box 12, The Hebrew University of Jerusalem, \\ Rehovot 76-100, Israel
}

Three novel mite-associated basidiomycetous species are described in two new anamorph genera as Meira geulakonigii gen. nov., sp. nov. (type CBS $110052^{\top}=\mathrm{NRRL} Y-27483^{\top}=A S 004^{\top}$ ), Meira argovae sp. nov. (type CBS $110053^{\top}=N R R L Y-27482^{\top}=A S 005^{\top}$ ) and Acaromyces ingoldii gen. nov., sp. nov. (type CBS $110050^{\top}=\mathrm{NRRL} Y-27484^{\top}=\mathrm{AS} 001^{\top}$ ). Morphologically, these fungi are similar to the yeast-like fungi classified in the Ustilaginales, such as Pseudozyma species. However, analysis of the D1/D2 domain of the LSU rDNA suggests that they belong to two different lineages within the Exobasidiomycetidae of the Ustilaginomycetes (Basidiomycota). Furthermore, these fungi may be of interest for the biocontrol of mites, as they reduced mite numbers by approximately $80 \%$ after inoculation.

\section{INTRODUCTION}

Mites (Acari) are among the major pests of commercial crops that annually require costly control measures. Prominent amongst the phytophagous Acari are spider mites (Tetranychidae) and rust mites (Eriophyidae). Many spider mites have developed extensive resistance to most available pesticides (Helle \& Sabelis, 1985), whereas rust mites, although less resistant to pesticides, are difficult to control because of their short generation time and their propensity to hide in galls and buds (Lindquist et al., 1996). These difficulties have engendered much interest in additional control options, especially in using natural enemies, such as other mites (Gerson \& Smiley, 1990). Interest in acaropathogenic fungi as biocontrol organisms for pest mites has increased in recent years, culminating in reviews dealing

Published online ahead of print on 28 February 2003 as DOI 10.1099/ ijs.0.02434-0.

Abbreviations: ITS, internal transcribed spacer; MEA, malt extract agar; PDA, potato dextrose agar; YMA, yeast extract/malt extract agar; YPGA, yeast extract/peptone/glucose agar.

The GenBank/EMBL/DDBJ accession numbers for isolates AS $001^{\top}$ to AS 006 are respectively AY158665-AY158670 (D1/D2 domain of LSU rDNA) and AY158671-AY158676 (ITS domain). with acarine mycoses (van der Geest et al., 2000) and with the use of fungi in mite control (Chandler et al., 2000). The two best-known acaropathogenic fungi are Neozygites floridana (Weiser \& Muma) Remaud \& S. Keller and Hirsutella thompsonii Fisher; the former is mostly apathogenic to spider mites, while the latter attacks mainly rust mites.

Within an ongoing project intended to develop fungi for mite control (Sztejnberg et al., 1997), we obtained several fungal isolates from cadavers of the citrus rust mite, Phyllocoptruta oleivira (Ashmead) (Eriophyidae), occurring on citrus leaves and fruit. These fungi, along with an isolate obtained from a dead carmine spider mite, Tetranychus cinnabarinus (Boisduval) (Tetranychidae), infesting castor beans, and another isolated from a citrus leaf, constitute the subject matter of this article.

A preliminary examination revealed that the fungi isolated from the mites belong to the Ustilaginales, or smut fungi, and share a number of morphological features with Pseudozyma Bandoni emend. Boekhout, from which they differ by rDNA sequences. In this paper, we suggest names for these novel fungi, describe their morphology, taxonomy and phylogeny and comment on the effect of one species on mites and on its potential use as a biocontrol agent. 


\section{METHODS}

Organisms studied. All fungi were collected in Israel and are deposited at Centraalbureau voor Schimmelcultures (CBS; Utrecht, The Netherlands), the ARS culture collection (NRRL; Peoria, IL, USA) and in the Department of Plant Pathology and Microbiology, Rehovot, Israel (AS numbers). Strain AS $001^{\mathrm{T}}$ (=CBS $110050^{\mathrm{T}}=$ NRRL Y-27484 ${ }^{\mathrm{T}}$ ) was isolated from the citrus rust mite on grapefruit (Citrus paradisi) leaves, south of the Sea of Galilee, in late 1995. Strain AS 002 (=CBS 110051) came from the citrus rust mite on pummelo (Citrus grandis), at Ga'aton, in the northern coastal plain. Strain AS 003 originated from the same mite and citrus hosts as AS $001^{\mathrm{T}}$, but at Beit She'an, south of the Sea of Galilee, in October 1996. Strain AS $004^{\mathrm{T}}\left(=\mathrm{CBS} 110052^{\mathrm{T}}=\mathrm{NRRL}\right.$ Y $-27483^{\mathrm{T}}$ ) also came from the same mite and plant hosts, collected in Dan (Upper Galilee) in October 1996. Strain AS $005^{\mathrm{T}}\left(=\mathrm{CBS} 110053^{\mathrm{T}}=\right.$ NRRL Y-27482 ${ }^{\mathrm{T}}$ ) was isolated in autumn 1996 at Nes Ziona (coastal plain) from a carmine spider mite on leaves of castor bean (Ricinus communis). Strain AS 006 came from the same area, from lemon leaves (Citrus limon) that were not infested by any mites, in November 1999. Mite cadavers or leaf particles were placed on $2 \%$ potato dextrose agar (PDA; Difco) in Petri dishes and observed for fungal growth. After 2-3 days, hyphae or conidia were isolated from the cadavers or the leaves and replated onto PDA.

Inoculation, morphology and physiology. Isolates AS $001^{\mathrm{T}}$, AS $004^{\mathrm{T}}$ and AS $005^{\mathrm{T}}$ were mass-cultured in the laboratory at $25^{\circ} \mathrm{C}$ on PDA and $2 \%$ malt extract agar (MEA; Difco). Maximal spore production occurred within 4-5 days. In order to explore biocontrol effects on mites, spores of isolate AS $004^{\mathrm{T}}\left(=\mathrm{CBS} 110052^{\mathrm{T}}\right)$ were washed off from cultures grown on PDA with deionized water and their concentration was adjusted to $10^{9}$ spores $\mathrm{ml}^{-1}$ with a haemocytometer. Citrus seedlings infested with the citrus rust mite and (separately) with the citrus red mite (Panonychus citri McGregor) and cucumbers infested by the carmine spider mite were sprayed with a suspension of $10^{9}$ spores $\mathrm{ml}^{-1}$, whereas control plants were sprayed only with water. Citrus seedlings were sprayed only once due to the small size of the citrus rust mite and the glabrous leaves. Cucumbers were sprayed six times, because the mites are much larger, they may move onto younger leaves and the leaves are hairy.

The morphology of the isolates was investigated using line inoculations on the following media: $1 \%$ yeast extract $/ 0.5 \%$ peptone $/ 4 \%$ glucose agar (YPGA), yeast extract/malt extract agar (YMA, Difco), yeast morphology agar (Difco), MEA, oatmeal agar (OA; Gams et al., 1987) and PDA. Plates were kept at $25^{\circ} \mathrm{C}$ for between 5 days and several weeks. Slides were made in water. Comparative nutritional tests were performed according to Boekhout (1991) and Yarrow (1998). Scanning electron microscopy (SEM) of mites that died during inoculation experiments was performed as described by Staugaard et al. (1990) and Weidenbörner et al. (1989).

rDNA sequencing and sequence analysis. Isolation of DNA was performed as described by Boekhout et al. (1995). The internal transcribed spacer (ITS) domains were amplified using primers V9 (5'-TGCGTTGATTACGTCCCTGC) and RLR3R (5'-GGTCCGTGTTTCAAGAC) in $50 \mu \mathrm{l}$ reaction volumes containing $30 \mu \mathrm{M}$ $\mathrm{MgCl}_{2}, 200 \mu \mathrm{M}$ of each dNTP, $1 \mu \mathrm{M}$ of each primer and $1 \mathrm{U}$ DNA polymerase. The following PCR conditions were used: initial denaturation of $5 \mathrm{~min}$ at $94^{\circ} \mathrm{C}$, followed by 35 cycles each with a denaturation step of $45 \mathrm{~s}$ at $94{ }^{\circ} \mathrm{C}$, annealing for $30 \mathrm{~s}$ at $52^{\circ} \mathrm{C}$ and an elongation step of $2 \mathrm{~min}$ at $72^{\circ} \mathrm{C}$ and a final elongation step of $6 \mathrm{~min}$ at $72^{\circ} \mathrm{C}$. The amplicons were purified using the GFX PCR DNA purification kit (Amersham Pharmacia Biotech). Aliquots of the PCR products containing 10-40 ng DNA were used in cyclesequencing reactions in a total volume of $10 \mu$ l, containing $1 \mu \mathrm{l} 5 \times$ sequencing buffer and $2 \mu \mathrm{l}$ BigDye terminator RR mix (both from
PE Biosystems) and $400 \mathrm{nM}$ primer. The sequencing primers used for the ITS $1,5 \cdot 8 \mathrm{~S}$ rDNA and ITS 2 were ITS 5 ( $5^{\prime}$-GGAAGTAAAAGTCGTAACAAGG) and ITS4 (5' ${ }^{\prime}$ TCCTCCGCTTATTGATATGC) and primers NL1 (5'-GCATATCAATAAGCGGAGGAAAAG) and RLR3R (5'GGTCCGTGTTTCAAGAC) were used for the LSU rDNA. Purification of these amplicons was performed by using the MultiScreen filtration system (Millipore) in combination with Sephadex G-50 Super fine (Amersham Pharmacia Biotech). Sequences were obtained with an ABI 3700 capillary sequencer (PE Biosystems) and further analysed using the Lasergene software package (DNASTAR Inc.). Phylogenetic trees were made with the PAUP 4.0b8a program using parsimony analysis, random step-wise addition and tree bisection-reconnection. Bootstrap values below $50 \%$ were not reported. Unfortunately, the available databases of the D1/D2 and ITS domains are not fully congruent. Therefore, it was not possible to use the same set of species in both analyses.

\section{RESULTS AND DISCUSSION}

\section{Morphology and physiology}

Approximately two-thirds of the mites used for isolation of fungi became covered with dense mycelia, which are described below. Colonies of isolate AS $001^{\mathrm{T}}$ remained whitish on PDA, whereas those of the other isolates showed various tinges of brown. Isolates AS 002, 003, $004^{\mathrm{T}}, 005^{\mathrm{T}}$ and 006 formed a brownish pigment on YPGA, YMA or PDA. Microscopically, all isolates shared the presence of acropetally formed, branched or unbranched, short chains of fusiform conidia (Figs 1 and 2), giving the colonies a somewhat velvety appearance (Fig. 3). Judging from the presence of the chains of blastoconidia, frequently originating from lateral sterigma-like structures occurring near the septa of narrow, hyaline hyphae, we initially identified these isolates as belonging to the genus Pseudozyma. SEM showed that blastoconidia were also formed on leaves and on dead mites (Fig. 2). The physiological characteristics of the isolates are presented in Table 1 . The basidiomycetous nature of the fungi was further supported by positive Diazonium blue B (DBB) tests and urease activities. The isolates did not ferment glucose, nor did they form extracellular starch-like compounds. Isolates AS 002, 003, $005^{\mathrm{T}}$ and 006 showed nearly identical assimilation patterns of carbon and nitrogen compounds, which differed from those of AS $001^{\mathrm{T}}$ and AS $004^{\mathrm{T}}$. The physiological patterns of these latter two isolates also differed from each other (Table 1). For instance, in contrast to strain AS $004^{\mathrm{T}}$, strain AS $001^{\mathrm{T}}$ was able to grow on melezitose, myo-inositol, nitrate and nitrite.

\section{rDNA analysis and comparison with closely related species}

Due to the rather uniform morphological characteristics of these fungi, we analysed the D1/D2 domain of the LSU rDNA, the internally transcribed spacers (ITS) and the $5 \cdot 8 \mathrm{~S}$ rDNA (Fell et al., 1995, 2000; Begerow et al., 2000, 2001, 2002). Sequence analysis of the D1/D2 domains of the LSU rDNA demonstrated that the novel isolates cluster within the Exobasidiomycetidae of the Ustilaginomycetes (Fig. 4). The closest relatives appeared to be Dicellomyces scirpi Raitv. 

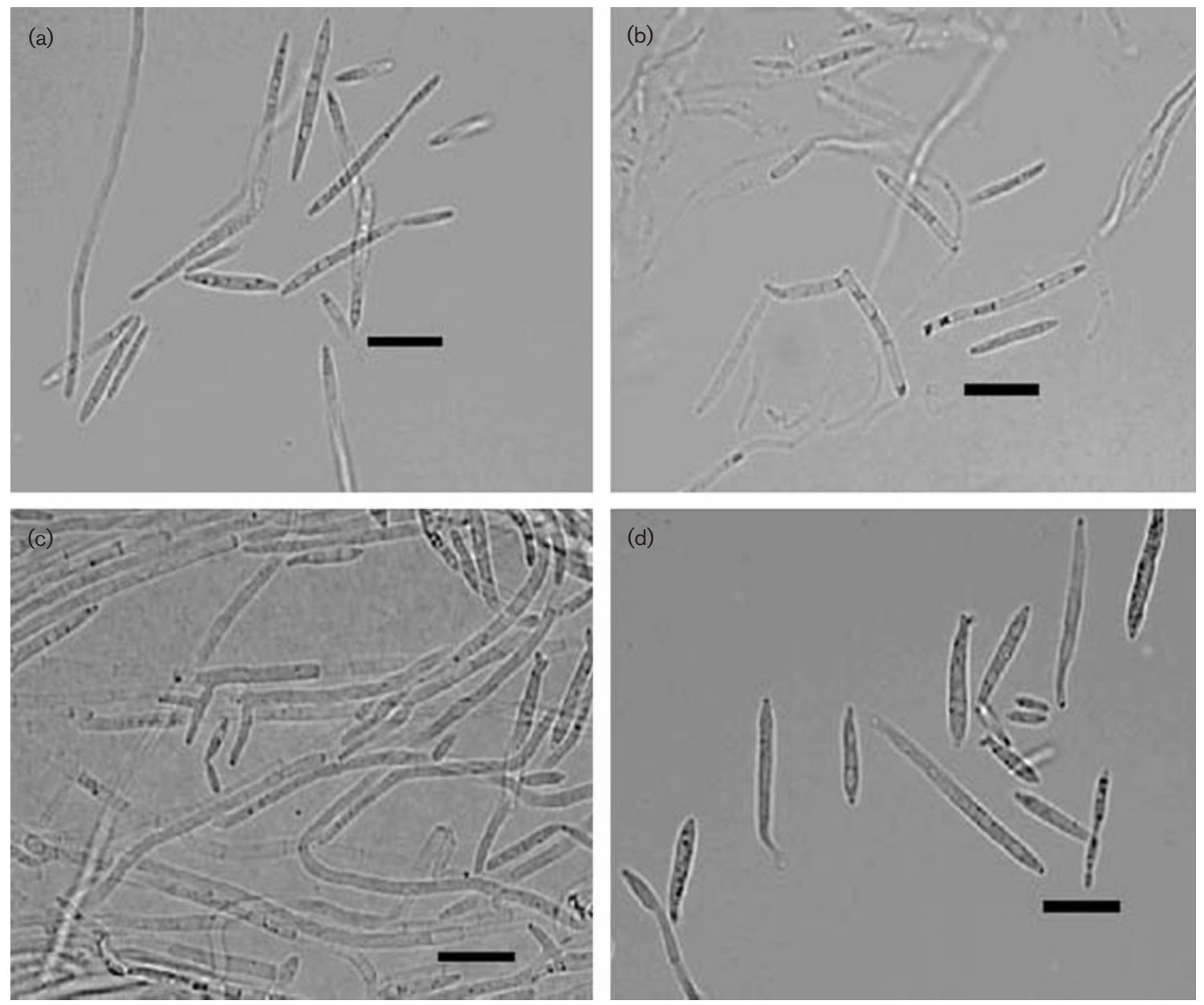

Fig. 1. Microscopic morphology of Meira argovae (a), Meira geulakonigii (b) and Acaromyces ingoldii (c, d), showing fusiform conidia, sterigma-like structures and hyphae. Bars, $10 \mu \mathrm{m}$.

and Kordyana spp., although the bootstrap values were lower than $50 \%$. These species have been classified in the Brachybasidiaceae of the Exobasidiales (Exobasidiomycetidae, Ustilaginomycetes) (Begerow et al., 2002). Graphiola phoenicis (Mougeot) Poiteau (Graphiolaceae) appears more distantly related (Fig. 4). Fungi belonging to the Brachybasidiaceaea have sexual states and are known as plant parasites (Kirk et al., 2001). Isolates AS 002, 003, $005^{\mathrm{T}}$ and 006 shared the same D1/D2 and ITS sequences. Isolate AS $004^{\mathrm{T}}$ belonged to the same cluster, but differed in $5 \mathrm{nt}$ in the D1/D2 sequence and $45 \mathrm{nt}$ plus three deletions in the ITS sequences. The isolates could not be identified with any known taxon of the Exobasidiales and we propose a new anamorphic genus, Meira gen. nov. Boekhout, Scorzetti, Gerson \& Sztejnberg. The systematic position of the genus Meira within the Exobasidiales is not yet clear, because of low bootstrap values. The Brachybasidiaceae may be a candidate family to accommodate these fungi, but Graphiolaceae or Exobasidiaceae are possible alternatives. It appears that additional sampling is required within this group of fungi to resolve this intraordinal phylogeny. The plant pathogen Muribasidiospora indica Kamat \& Rajendren is also classified in the Exobasidiales (Rajendren, 1969; Begerow et al., 2001), but the culture of that species differs from that of Meira by the presence of pigmented hyphae and abundant chlamydospores (Rajendren, 1970).

Strain AS $001^{\mathrm{T}}$ differed from the remaining isolates in a considerable number of nucleotides and formed a wellsupported cluster (bootstrap value $100 \%$ ) with Clinoconidium bullatum $\mathrm{H}$. Syd. The cluster of these two species with Coniodictyum chevalieri Har. \& Pat. was supported by a bootstrap value of only $55 \%$ (Fig. 4). We concluded that strain AS $001^{\mathrm{T}}$ may belong to the Cryptobasidiaceae of the Exobasidiales (Exobasidiomycetidae, Ustilaginomycetes, Basidiomycetes) but, again, further sampling and expansion of the set of organisms and genes are required to settle this issue. However, this phylogenetic position of isolate AS $001^{\mathrm{T}}$ suggests that it belongs to a genus separate from the other five mite-associated fungi. Strain $\mathrm{AS} 001^{\mathrm{T}}$ could not be identified with any known taxon within the Exobasidiomycetidae and we therefore propose a new genus, Acaromyces 

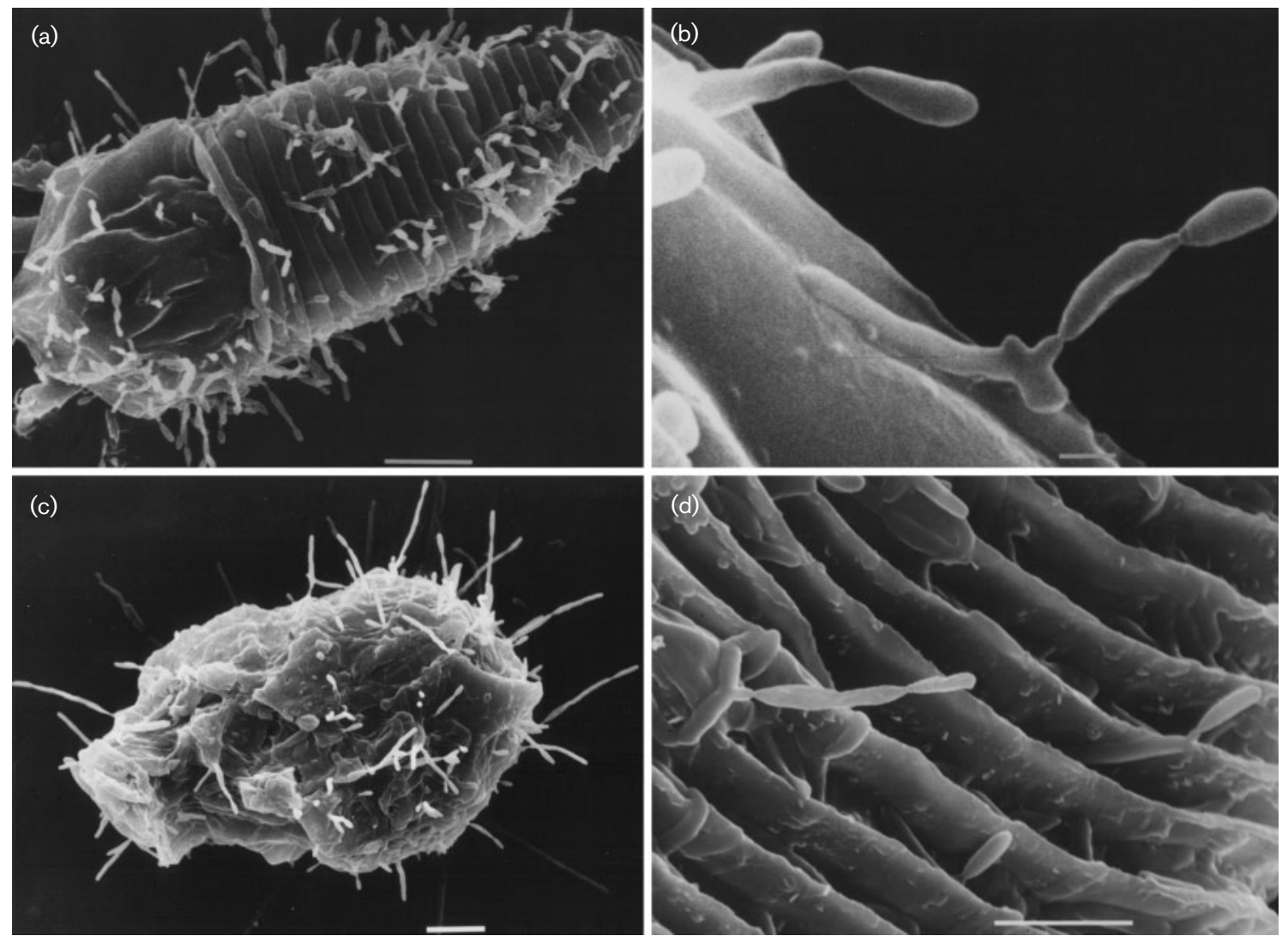

Fig. 2. Scanning electron micrographs of Meira geulakonigii and Meira argovae. (a) Sporulation of Meira geulakonigii on a mite. (b) Detail of acropetally formed chain of blastoconidia of Meira geulakonigii on a mite. (c) Sporulation of Meira argovae on a mite. (d) Detail of acropetally formed chain of blastoconidia of Meira argovae on a mite. Bars, 10 (a, c), 5 (d) or 1 (b) $\mu \mathrm{m}$.

gen. nov. Boekhout, Scorzetti, Gerson \& Sztejnberg, to accommodate this fungus. In contrast to most other genera of the Exobasidiomycetidae, which have sexual stages

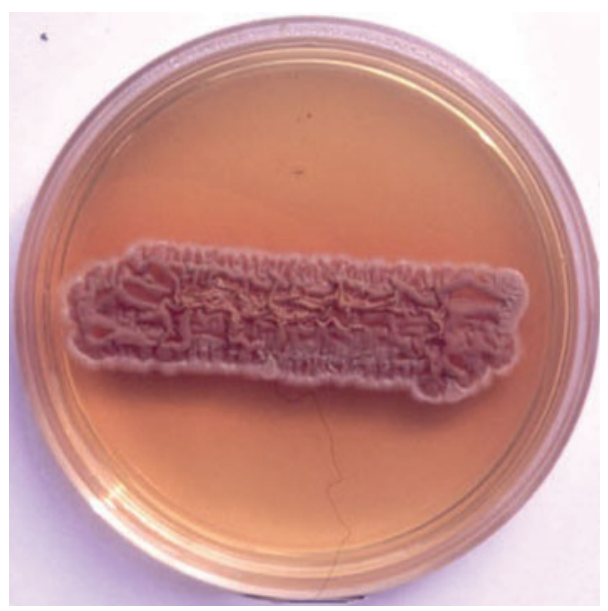

Fig. 3. Culture of Meira geulakonigii CBS $110052^{\top}$ (isolate $^{\top}$ AS $004^{\top}$ ) on PDA after 11 days. and mainly occur as plant parasites (Begerow et al., 2002), Acaromyces is an asexual genus known from mites. Interestingly, the conidial state of Coniodyctium chevalieri, as depicted by Malençon (1953), has a gross morphology similar to that of Acaromyces.

A number of other fungi form similar acropetally fusiform blastoconidia in chains. The most notable are Hyalodendron Diddens, Fusidium Link (and close relatives), Pseudozyma Bandoni emend. Boekhout and Sympodiomycopsis paphiopedili Sugiyama et al. Molecular studies showed that Hyalodendron belongs to the Hymenomycetes (Guého et al., 1993), Pseudozyma species cluster within the Ustilaginales (Ustilaginomycetidae) (Begerow et al., 2000) and S. paphiopedili forms a cluster together with Microstoma juglandis (Berenger) Saccardo and may belong to the Microstromatales (Begerow et al., 2000). Fusidium-like anamorphs belong to the Ascomycetes (Boekhout, 1995; Kirk et al., 2001). Because of the observed differences, we propose to classify these mite-associated fungi in two anamorph genera, Meira and Acaromyces, belonging to the Exobasidiomycetidae (Ustilaginomycetes, Basidiomycota). From a morphological point of view, the mite-associated fungi cannot be differentiated easily from Pseudozyma spp., 
Table 1. Physiological characteristics of Acaromyces ingoldii, Meira geulakonigii and Meira argovae

Characteristics are scored as: +, growth; -, no growth; w, weak growth; D, delayed growth (after 2 or more weeks). Isolates AS 002, AS 003 and AS 006 gave identical results to AS $005^{\mathrm{T}}$. All three taxa are positive for assimilation of the carbon compounds D-glucose, D-xylose, sucrose, maltose, $\alpha, \alpha$-trehalose, raffinose, D-glucitol, D-mannitol and succinate and the nitrogen compound cadaverine. All three taxa are positive for the DBB reaction and growth at 25 and $30^{\circ} \mathrm{C}$. All three taxa show delayed growth on propane-1,2-diol. All three taxa are negative for fermentation of D-glucose, assimilation of the carbon compounds L-sorbose, D-glucosamine, L-rhamnose, methyl $\alpha$-glucoside, 2-ketoD-gluconate, D-galacturonate, methanol, butane-2,3-diol, saccharate and galactonic acid and the nitrogen compounds creatinine, glucosamine and imidazole, growth on $50 \%$ glucose, starch production and growth at $40{ }^{\circ} \mathrm{C}$.

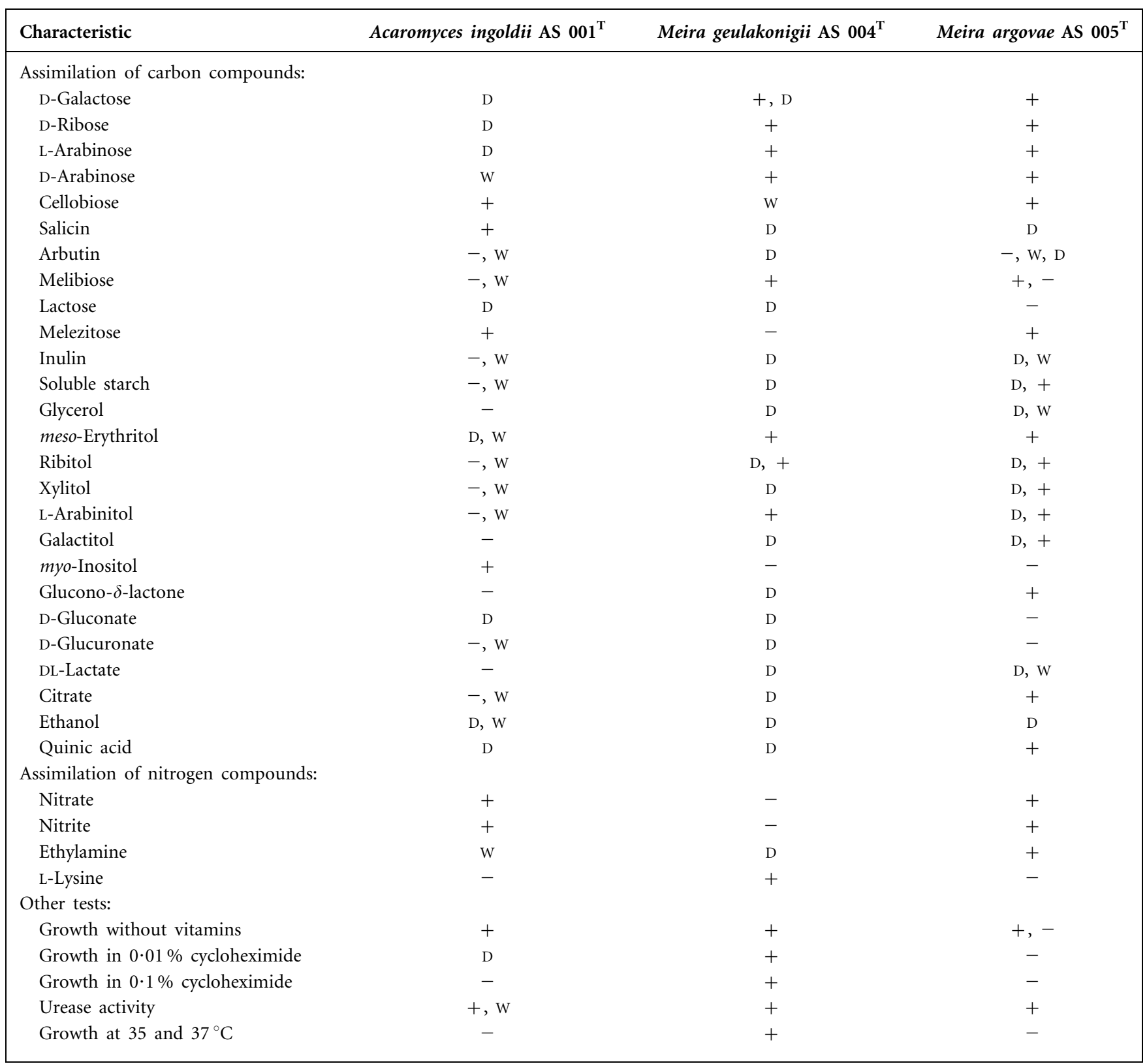

because these species are also characterized by the presence of acropetal chains of fusiform conidia originating from sterigma-like structures occurring on narrow, hyaline and septate hyphae. However, as our sequence analysis clearly demonstrated that the mite-associated fungi do not belong to the Ustilaginomycetidae, we recognize them as separate genera.
Asexual smut fungi have been neglected because of taxonomic difficulties. Until the introduction of comparative sequencing of rDNA, it was almost impossible to appreciate the phylogenetic diversity of these fungi, since many isolates share a similar morphology and nutritional physiology (Boekhout, 1987, 1995; Boekhout et al., 1995). Several anamorphic members of the Ustilaginales were originally 


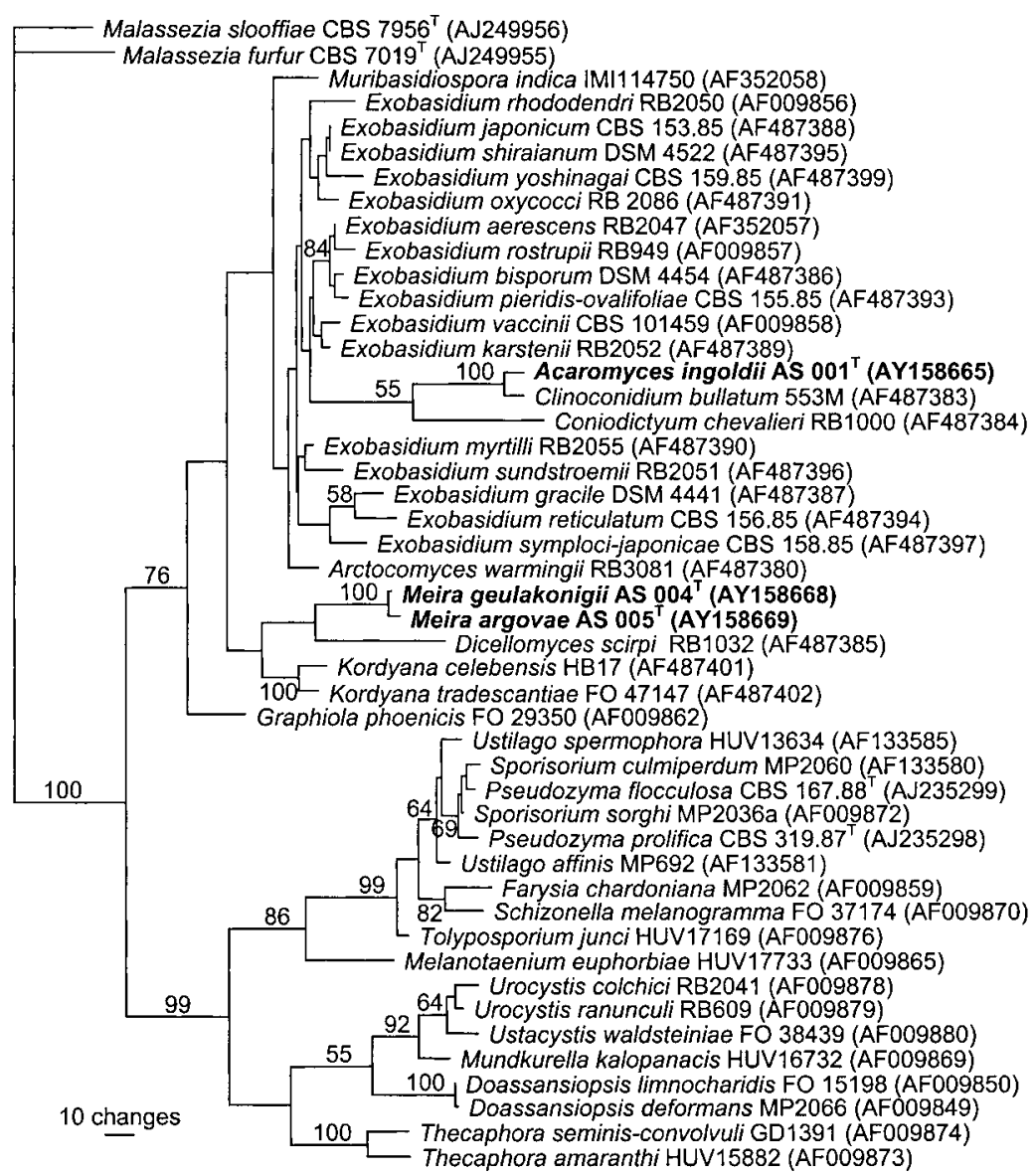

Fig. 4. Dendrogram based on sequences of the D1/D2 domains of the LSU rDNA demonstrating that isolates AS $001^{\top}$, AS $004^{\top}$ and $\mathrm{AS} 005^{\top}$ cluster within the Exobasidiomycetidae of the Ustilaginomycetes (Basidiomycota). Accession numbers are given in parentheses. Bar, 10 changes. described in different genera, and some were even considered to belong to the Ascomycetes (Traquair et al., 1988; Boekhout, 1987, 1995; Boekhout et al., 1995). Sequence analysis of the LSU rDNA suggested that all Pseudozyma anamorphs belong to the Ustilaginales, which parasitize grasses (Ustilaginomycetidae, Ustilaginomycetes) (Begerow et al., 2000; Fell et al., 2000).

The life cycle of these mite-associated fungi, as well as those of most Pseudozyma species, is poorly known. Two alternatives seem possible. Either they represent the haplophase of otherwise sexual plant-pathogenic smuts, and the relationship between the anamorph and teleomorph fungi has not yet been established, or they are truly asexual fungi that originated from these plant pathogens.

\section{Applied aspects}

In a preliminary experiment, isolate AS $004^{\mathrm{T}}$ reduced mite numbers by $\sim 80 \%$ within 1 week, thus demonstrating a high potential to control mites. We do not know whether the infected mites found in the field died as a result of fungal infection under natural conditions. However, the facts that our fungi were, in most cases, isolated from dead mites and that conidia from cultures of the very same fungi killed mites under laboratory conditions strongly suggest that mites may also be killed by the fungi under natural conditions.
A number of other smut anamorphs also have interesting biocontrol features. For example, Pseudozyma flocculosa (Traquair, L. A. Shaw \& Jarvis) Boekhout \& Traquair is a well-documented biocontrol agent of powdery mildew (Paulitz \& Belangér, 2001). Other interesting applied features of smut anamorphs are the accumulation of lipids ( 41\% of the dry weight) by Candida 107 (Gill et al., 1977), which seems closely related to Pseudozyma antarctica (Goto et al.) Boekhout (T. Boekhout, unpublished), and the production of extracellular mannosylerythritol lipids and commercially exploited B-lipase by $P$. antarctica (Anderson et al., 1998; Kitamoto et al., 1990). We do not know whether the currently described fungi also share these properties, but it may be very interesting to explore this in the future.

\section{Latin diagnosis of Meira Boekhout, Scorzetti, Gerson \& Sztejnberg gen. nov.}

Genus anamorphicum Exobasidiomycetidarum (Ustilaginomycetes, Basidiomycota). Coloniis dimorphicis, primum zymoideis, cellulis fusiformibus, ad apicem e rachide acropetali proliferentibus; deinde hyphae septatae, hyalinae, vulgo cytoplasmate contracto, cellulis evacuatis separatae. Protuberantiae sterigmatoideae saepe prope septa formatae, e quibus catenae breves blastoconidiorum oriuntur. Mycelium aerium tenue e blastoconidiis constans coloniis aspectum velutinum praebens. Myo-inositolum haud assimilatur, nec amylum 
extracellulare formatum. Reactiones DBB et ureasi positivae. Typus Meira geulakonigii Boekhout, Scorzetti, Gerson \& Sztejnberg.

\section{Description of Meira Boekhout, Scorzetti, Gerson \& Sztejnberg gen. nov.}

Meira [Meir'a. Hebrew fem. n. meira light, to express the feeling of three of the authors (A. S., U. G., A. G.) after the phylogenetic position of the fungi was resolved, and also named after the wife of A. G.].

Anamorphic fungi, belonging phylogenetically to the Exobasidiomycetidae (Ustilaginomycetes, Basidiomycota), with dimorphic colonies. Initial yeast-like growth with fusiform cells showing polar budding on an acropetal rachis. Septate hyphae hyaline, usually with the cytoplasm retracted in cells, separated by lysed cells. Sterigma-like outgrowths, frequently occurring near the septa, give rise to short chains of fusiform blastoconidia. Thin aerial mycelium, made up of these blastoconidia, give the colony a somewhat velvety appearance. myo-Inositol is not assimilated and extracellular starch is not produced, DBB and urease reactions are positive.

The type species is Meira geulakonigii Boekhout, Scorzetti, Gerson \& Sztejnberg. So far, the type species and Meira argovae are known only from mites, but it is not known whether their occurrence is limited to these animals.

\section{Latin diagnosis of Meira geulakonigii Boekhout, Scorzetti, Gerson \& Sztejnberg sp. nov.}

Coloniae in agaro YPGA dicto post 4 dies convexae, superficie venosa vel cerebriformi, marginem versus sulcatae, synnematibus obtectae, margine integra. In agaro morphologiae post 48 horas $\sim 6 \mathrm{~mm}$ diam., convexae, paulatim conspicue sulcatae, partim synnematibus angustatis obtectae, sed etiam in sectoribus leves, haud lucidae, cremeo-albae; margo regularis. In agaro YPGA dicto post 3 hebdomades $\sim 30 \mathrm{~mm}$ diam., albae, marginem versus pallide luteo-brunneae; superficies velutina pruinosa, partim arachnoidea; in medio plana vel modice elevata et verruculosa vel sulcata, marginem versus radiatim sulcata; margo integra vel modice erosa et sectoribus divisa. In agaro YMA dicto coloniae in medio synnematibus obtectae, marginem versus magis planae, cremeo-albae. In agaro PDA dicto post 25 hebdomades $40 \mathrm{~mm}$ diam., haud lucidae, obscure griseo-brunneae; in medio planae vel modice verrucosae et synnematibus angustatis obtectae, marginem versus sulcatae. Pigmentum brunneum in omnibus agaris diffundens. Primum cellulae zymosae fusiformes, $7-17 \times 2-$ $3 \mu \mathrm{m}$, utrinque sympodialiter proliferentes; hyphae $\sim 2-3 \mu \mathrm{m}$ latae, plerumque partim evacuatae, ad septa modice constrictae, nonnumquam in arthroconidia fragmentatae; catenae acropetales conidiorum ellipsoidalium vel fusiformium, 5-17 $\times 2-4 \mu \mathrm{m}$ e protuberantiis sterigmatoideis et e latere et apice hypharum oriuntur. Proprietates physiologicae in Tabella 1 compositae. Typus AS $004^{\mathrm{T}}\left(=\mathrm{CBS} 110052^{\mathrm{T}}=\right.$ NRRL Y-27483 ${ }^{\mathrm{T}}$.

\section{Description of Meira geulakonigii Boekhout, Scorzetti, Gerson \& Sztejnberg sp. nov.}

Meira geulakonigii (geu.la.kon.ig'i.i. N.L. adj. geulakonigii of Geula Konig, to commemorate the sister of A. G., who died during the course of the present study).

Colonies on YPGA after 4 days are highly convex, whitish, with the surface venose to cerebriform, radially furrowed near the margin, pruinose and covered with synnemata with entire margins. On morphology agar after $48 \mathrm{~h}$, colonies are about $6 \mathrm{~mm}$ in diameter, convex, but becoming strongly furrowed, partly covered with tapered synnemata, but also with smooth sectors, dull, creamy white, with sharp margins. After 3 weeks on YPGA, colonies are about $30 \mathrm{~mm}$ in diameter, white, but pale greyish brown near the margin; finely velvety pruinose and, at places, somewhat arachnoid; centre about $15 \mathrm{~mm}$ in diameter, flat to somewhat elevated and somewhat warty to ridged, radially furrowed near the margin; margin entire or somewhat eroded and with sectors. On YMA, colonies are whitish pruinose and the centre is covered with synnemata, which become flattened towards the margin. On PDA, colonies are $40 \mathrm{~mm}$ in diameter, dull, dark greyish brown, with the centre $6 \mathrm{~mm}$ in diameter, flat to somewhat warty and with tapered synnemata and radially furrowed toward the marginal zone; the marginal zone is greyish brown, flat and outermost margin eroded; reverse dark brown. Brown pigment exudes on YPGA, YMA, MEA and PDA. Initial growth with ellipsoidal yeast cells, 7-17 $\times$ 2-3 $\mu \mathrm{m}$, with polar sympodial budding; hyphae approximately $2-3 \mu \mathrm{m}$ in diameter, usually partly lysed and somewhat constricted near the septa, may disarticulate into arthroconidia-like cells; acropetal chains of ellipsoidal to fusiform conidia, $5-17 \times 2-4 \mu \mathrm{m}$ in size, originate on sterigma-like structures laterally or terminally on the hyphae (Fig. 1b); short chains of conidia are also formed on mites (Fig. 2a, b). Physiological characteristics are presented in Table 1.

Meira geulakonigii differs from Meira argovae in that it does not assimilate nitrate and nitrite, it assimilates L-lysine, it shows cycloheximide resistance, it is able to grow at 35 and $37^{\circ} \mathrm{C}$ and its hyphae are somewhat constricted near the septa. Moreover, the rDNA sequence of Meira geulakonigii differs from that of Meira argovae in $5 \mathrm{nt}$ in the D1/D2 domain (LSU rDNA), $35 \mathrm{nt}$ in the ITS1, $1 \mathrm{nt}$ in the $5 \cdot 8 \mathrm{~S}$ rDNA and $10 \mathrm{nt}$ in the ITS2 in addition to three deletions, of 6,7 and $11 \mathrm{nt}$.

The type is isolate AS $004^{\mathrm{T}}\left(=\mathrm{CBS} 110052^{\mathrm{T}}=\mathrm{NRRL}\right.$ as $\mathrm{Y}-27483^{\mathrm{T}}$ ), also preserved as a dried specimen in the herbarium CBS (Utrecht, The Netherlands), which was isolated from the citrus rust mite infesting grapefruit (C. paradisi) at Dan (Upper Galilee, Israel).

\section{Latin diagnosis of Meira argovae Boekhout, Scorzetti, Gerson \& Sztejnberg sp. nov.}

Coloniae in agaro YPGA dicto post 48 horas $\sim 4 \mathrm{~mm}$ diam., puctiformes vel convexae; post 3 hebdomades $\sim 12 \mathrm{~mm}$ 
diam., in medio verrucosae, pulvinatae vel irregulariter rugosae, demum superficie valde irregulari, sed marginem versus planae; primum albidae, deinde pallide brunneo; superficies alba velutina vel pruinosa; margo erosa; reversum luteo-brunneum vel brunneum. Post 3 hebdomades in agaro MEA dicto ad $30 \mathrm{~mm}$ diam., in medio convexae; griseobrunneae; superficies verrucosa vel sulcata vel reticulata, synnematibus sursum angustatis obtecta. In agaro PDA dicto post 3 hebdomades coloniae ad $\sim 30 \mathrm{~mm}$ diam., in medio plus minusve planae vel irregulariter cristatae, leves, in medio lucide luteo-brunneae, marginem planam versus pallidiores. Pigmentum brunneum in omnes agaros diffundens. In coloniis juvenibus cellulae fusiformes zymoideae, 7-20 × 1.5-2.5 $\mu \mathrm{m}$, ad apicem e rachide sympodiali proliferentes; in coloniis vetustioribus hyphae angustae, $\sim 1 \cdot 5-2 \cdot 0 \mu \mathrm{m}$ latae, ad septa haud constrictae, partim evacuatae; catenae acropetales conidiorum fusiformium e protuberantiis sterigmatoideis nonnumquam sympodialiter proliferentibus iuxta septa hyphalia oriuntur. Conidia basilaria $8-25 \times 1 \cdot 0-2 \cdot 5 \mu \mathrm{m}$, apicem versus breviora, $3-10 \times 1-2 \mu \mathrm{m}$; e rachide sympodiali germinantia. Proprietates physiologicae in Tabella 1 compositae. Typus AS $005^{\mathrm{T}}\left(=\mathrm{CBS} 110053^{\mathrm{T}}=\mathrm{NRRL} \mathrm{Y}-27482^{\mathrm{T}}\right)$.

\section{Description of Meira argovae Boekhout, Scorzetti, Gerson \& Sztejnberg sp. nov.}

Meira argovae (ar.go'va.e. N.L. adj. argovae of Argov, to recognize Y. Argov, who collected most of the infected mites).

Colonies on YPGA after $48 \mathrm{~h}$ are about $4 \mathrm{~mm}$ in diameter, punctiform to highly convex; after 3 weeks, about $12 \mathrm{~mm}$ in diameter, with the centre warty, pulvinate to irregularly ridged, finally becoming strongly uneven, but flat towards the margin; at first whitish, but soon becoming pale greyish brown; the surface is finely white velvety pruinose, with hairy synnemata; margin eroded; reverse brown. After 3 weeks on MEA, colonies are up to about $30 \mathrm{~mm}$ in diameter, with the centre convex; surface greyish brown, warty, ridged, furrowed to reticulate and covered with tapered synnemata that flatten towards the margin. After 3 weeks on PDA, colonies are up to about $30 \mathrm{~mm}$ in diameter, with the centre more or less flat or irregularly ridged, smooth, with the centre shiny yellowish brown (isabellina), gradually changing into a flat marginal zone; brown pigment exudes on YMA, YPGA, MEA and PDA. Isolate AS 003 differs by wider expansion of the colonies (e.g. $65 \mathrm{~mm}$ on YPGA after 3 weeks) and a more whitish colony with a pale reverse. Young colonies (after $48 \mathrm{~h}$ ) consist of fusiform yeast cells, $7-20 \times 1 \cdot 5-2.5 \mu \mathrm{m}$, with polar budding on a sympodial rachis; in older colonies, slender, hyaline hyphae occur, approximately $1 \cdot 5-2 \cdot 0 \mu \mathrm{m}$ wide, without constrictions near the septa and usually partly lysed; acropetal chains of fusiform conidia originate on sterigma-like structures, which may be sympodially branched and usually occur near the hyphal septa; conidia are $8-25 \times 1 \cdot 0-2.5 \mu \mathrm{m}$ at the base of the chain and 3-10 $\times 1-2 \mu \mathrm{m}$ near the apex (Fig. 1a); they germinate with a terminal sympodial rachis; short conidial chains also occur on mites (Fig. 2c, d). The physiological characteristics of the species are presented in Table 1.

The type, isolate AS $005^{\mathrm{T}}\left(=\mathrm{CBS} 110053^{\mathrm{T}}=\right.$ NRRL Y$27482^{\mathrm{T}}$ ), also preserved as a dried specimen in the herbarium CBS (Utrecht, The Netherlands), was isolated in autumn 1996 at Nes Ziona (coastal plain, Israel) from a carmine spider mite on leaves of castor bean (Ricinus communis). The other isolates reported here (AS 002, 003 and 006) are also from Israel.

\section{Latin diagnosis of Acaromyces Boekhout, Scorzetti, Gerson \& Sztejnberg gen. nov.}

Fungi anamorphici Cryptobasidiaceae, Exobasidiomycetidarum, Exobasidio affines (Ustilaginomycetes, Basidiomycota). Hyphae septatae, plerumque cytoplasmate contracto, cellulae alteris evacuatis separatae. Protuberantiae sterigmatoideae saepe iuxta septa oriundae, catenas blastoconidiorum proferentes. Mycelium aerium e blastoconidiis constans coloniis aspectum modice velutinum pruinosum praebens. Myo-inositolum assimilar, amylum extracellulare haud formatum. Reactiones DBB et ureasi positivae. Typus Acaromyces ingoldii Boekhout, Scorzetti, Gerson \& Sztejnberg.

\section{Description of Acaromyces Boekhout, Scorzetti, Gerson \& Sztejnberg gen. nov.}

[non Acaromyces Lavie nomen nudum, no description, no Latin diagnosis and no type material indicated $=$ Kloeckera apiculata) (Lavie, 1950)].

Acaromyces (A.ca.ro.my'ces. N.L. n. acari from Gr. n. akari mite; N.L. n. myces from Gr. n. mukes fungus; N.L. n. Acaromyces mite fungus).

Anamorphic fungus, belonging phylogenetically to the Cryptobasidiaceae, Exobasidiomycetidae (Ustilaginomycetes, Basidiomycota). Hyphae septate, usually with the cytoplasm retracted in cells separated by lysed cells. Sterigma-like outgrowths occur frequently near the septa, giving rise to chains of fusiform blastoconidia. Aerial mycelium thin and made up of blastoconidia, giving the colony a somewhat velvety-pruinose appearance. myo-Inositol is assimilated and extracellular starch is not produced. DBB and urease reactions are positive.

The type species is Acaromyces ingoldii Boekhout, Scorzetti, Gerson \& Sztejnberg.

\section{Latin diagnosis of Acaromyces ingoldii Boekhout, Scorzetti, Gerson \& Sztejnberg sp. nov.}

Coloniae in agaro YPGA dicto post 7 dies $8 \mathrm{~mm}$ diam., e microcoloniis fusis constantes; haud lucidae, albidae, modice elevatae vel pulvinatae, tenaces, margine integra vel nonnullis hyphis radiantibus fimbriata; post 3 hebdomades coloniae $\sim 16 \mathrm{~mm}$ diam., superficie sulcata, verrucosa vel cerebriformi, marginem versus radiatim sulcata, albidae; mycelio tenui 
pruinoso aerio obtectae; margo erosa; reversum dilute luteobrunneum. In agaro PDA post 27 hebdomades coloniae $\sim 25 \mathrm{~mm}$ diam., in medio irregulariter sulcatae, margine plano, erosa; primum albidae, velutinae pruinosae, sed cito griseo-brunneae partim maculis albis velutinis obtectae; reversum brunneum, marginem versus partim crystallis cylindricis vel acuformibus aggregatis luteum. Hyphae septatae, $\sim 1-2 \mu \mathrm{m}$ latae, cytoplasmate contracto, cellulae alteris evacuatis separatae. Protuberantiae sterigmatoideae, sympodialiter proliferentes, iuxta septa formatae, catenas conidiorum fusiformium vel lanteolatorum proferentes. Blastoconidia basilaria $20-35 \times 23 \mu \mathrm{m}$, apicem versus breviora, 6-15 × 1.5-3 $\mu \mathrm{m}$. Myo-inositolum assimalatur, amylum exctracellulare haud formatum. Reactiones DBB et ureasi positivae. Proprietates physiologicae in Tabella 1 compositae. Typus AS $001^{\mathrm{T}} \quad\left(=\mathrm{CBS} 110050^{\mathrm{T}}=\mathrm{NRRL}\right.$ $\left.\mathrm{Y}-27484^{\mathrm{T}}\right)$.

\section{Description of Acaromyces ingoldii Boekhout, Scorzetti, Gerson \& Sztejnberg sp. nov.}

Acaromyces ingoldii (in.gol'di.i. N.L. adj. ingoldii of Ingold, to recognize the contribution of T. C. Ingold to mycology).

Colonies on YPGA after 1 week are $8 \mathrm{~mm}$ in diameter, consisting of interconnected smaller colonies; dull, white, somewhat raised to pulvinate, tough, with the margin entire, but some radiating hyphae may occur on the surface of the agar plate. After 3 weeks, colonies are about $16 \mathrm{~mm}$ in diameter, with the surface furrowed, warty to cerebriform, and radially furrowed near the margin; dull, whitish; covered with thin pruinose aerial mycelium; margin somewhat eroded; reverse pale yellowish brown (isabella). On PDA, colonies are about $25 \mathrm{~mm}$ in diameter, with centre about $8 \mathrm{~mm}$, irregularly ridged and furrowed, with flat marginal zone and eroded outermost margin; whitish at first, velvety pruinose, but soon becoming greyish brown and covered with white velvety patches; reverse brown; submerged yellowish patches of cylindrical to needle-shaped crystals near the margin; no exuding brown pigment. Hyphae septate, approximately 1-2 $\mu \mathrm{m}$ wide, with the cytoplasm retracted in cells separated by lysed cells; sterigma-like outgrowths, which may be sympodially branched, occur near the septa and give rise to chains of fusiform to lanceolate blastoconidia. Blastoconidia are $20-35 \times 23 \mu \mathrm{m}$, shorter near the apex of the chain, $6-15 \times 1 \cdot 5-3 \mu \mathrm{m}$ (Fig. 1c, d). myo-Inositol is assimilated and extracellular starch is not produced; DBB and urease reactions are positive. The physiological characteristics of the species are given in Table 1.

Can be differentiated from the two Meira species because it assimilates $m y o$-inositol and does not utilize glucono- $\delta$ lactone. More importantly, the rDNA sequence indicates that the species belongs to a different lineage within the Exobasidiomycetidae. The morphologically similar genus Pseudozyma belongs to a different clade in the Ustilaginomycetidae, namely the Ustilaginales.
The type and only strain, AS $001^{\mathrm{T}}\left(=\mathrm{CBS} 110050^{\mathrm{T}}=\mathrm{NRRL}\right.$ Y-27484 $4^{\mathrm{T}}$ ), also preserved in the herbarium CBS (Utrecht, The Netherlands), was isolated from a mite [citrus rust mite infesting grapefruit (C. paradisi) leaves, south of the Sea of Galilee, Israel], but it is not known whether the occurrence of the fungus is confined to mites.

\section{ACKNOWLEDGEMENTS}

A. G., U. G. and A.S. wish to thank Dr Y. Argov, of The Israel Cohen Institute for Biological Control, Citrus Marketing Board of Israel, Bet Dagan, Israel, for collecting the infected mites as well as Mr Z. Paz and Dr R. Mozes-Koch, both of the Faculty of Agricultural, Food and Environmental Sciences, Rehovot, Israel, for expert technical support during this study. T. B. wants to thank Professor Dr W. Gams for providing the Latin diagnoses and helpful discussions on the manuscript. Research by G.S. was funded by the US National Science Foundation, Division of Environmental Biology, Biotic Systems and Inventories.

\section{REFERENCES}

Anderson, E. M., Larsson, K. M. \& Kirk, O. (1998). One biocatalyst many applications: the use of Candida antarctica B-lipase in organic synthesis. Biocatal Biotransform 16, 181-204.

Begerow, D., Bauer, R. \& Boekhout, T. (2000). Phylogenetic placements of ustilaginomycetous anamorphs as deduced from nuclear LSU rDNA sequences. Mycol Res 104, 53-60.

Begerow, D., Bauer, R. \& Oberwinkler, F. (2001). Muribasidiospora: Microstromatales or Exobasidiales? Mycol Res 105, 798-810.

Begerow, D., Bauer, R. \& Oberwinkler, F. (2002). The Exobasidiales: an evolutionary hypothesis. Mycol Progr 1, 187-199.

Boekhout, T. (1987). Anamorphs of smut fungi. Stud Mycol 30, 137-149.

Boekhout, T. (1991). A revision of ballistoconidia-forming fungi. Stud Mycol 33, 1-194.

Boekhout, T. (1995). Pseudozyma Bandoni emend. Boekhout, a genus for yeast-like anamorphs of Ustilaginales. J Gen Appl Microbiol 41, 359-366.

Boekhout, T., Fell, J. W. \& O'Donnell, K. (1995). Molecular systematics of some yeast-like anamorphs belonging to the Ustilaginales and Tilletiales. Stud Mycol 38, 175-183.

Chandler, D., Davidson, G., Pell, J. K., Ball, B. V., Shaw, K. \& Sunderland, K. D. (2000). Fungal biocontrol of acari. Biocontrol Sci Technol 10, 357-384.

Fell, J. W., Boekhout, T. \& Freshwater, D. W. (1995). The role of nucleotide sequence analysis in the systematics of the yeast genera Cryptococcus and Rhodotorula. Stud Mycol 38, 129-146.

Fell, J. W., Boekhout, T., Fonseca, A., Scorzetti, G. \& StatzellTallman, A. (2000). Biodiversity and systematics of basidiomycetous yeasts as determined by large-subunit rDNA D1/D2 domain sequence analysis. Int J Syst Evol Microbiol 50, 1351-1371.

Gams, W., van der Aa, H. A., van der Plaats-Niterink, A. J., Samson, R. A. \& Stalpers, J. A. (1987). CBS Course of Mycology. Baarn: CBS.

Gerson, U. \& Smiley, R. L. (1990). Acarine Biocontrol Agents, an Illustrated Key and Manual. London: Chapman \& Hall.

Gill, C. O., Hall, M. J. \& Ratledge, C. (1977). Lipid accumulation in an oleaginous yeast (Candida 107) growing on glucose in single-stage continuous culture. Appl Environ Microbiol 33, 231-239. 
Guého, E., Improvisi, L., Christen, R. \& de Hoog, G. S. (1993). Phylogenetic relationships of Cryptococcus neoformans and some related basidiomycetous yeasts determined from partial large subunit rRNA sequences. Antonie van Leeuwenhoek 63, 175-189.

Helle, W. \& Sabelis, M. W. (1985). Spider Mites, their Biology, Natural Enemies and Control, vols I and II. Amsterdam: Elsevier.

Kirk, P. M., Cannon, P. F., David, J. C. \& Stalpers, J. A. (2001). The Dictionary of Fungi, 9th edn. Egham, UK: CABI Publishing.

Kitamoto, D., Haneishi, K., Nakahara, T. \& Tabuchi, I. (1990). Production of mannosylerythritol lipids by Candida antarctica from vegetable oil. Agric Microbiol Chem 54, 37-40.

Lavie, P. (1950). Sur un organisme énigmatique Acaromyces laviae, qui semble s'attaquer à l'Acarapis woodi. L'Apiculteur 3, 41-45.

Lindquist, E. E., Sabelis, M. W. \& Bruin, J. (editors) (1996). Eriophyoid Mites, their Biology, Natural Enemies and Control. Amsterdam: Elsevier.

Malençon, G. (1953). Le Coniodyctium chevalieri Har. et Pat., sa nature et ses affinités. Bull Trimest Soc Mycol Fr 69, 77-100.

Paulitz, T. C. \& Belangér, R. R. (2001). Biological control in greenhouse systems. Annu Rev Phytopathol 39, 103-133.

Rajendren, R. B. (1969). Muribasidiosporaceae: a new family of Hymenomycetes. Mycologia 61, 1159-1160.
Rajendren, R. B. (1970). Muribasidiospora indica in artificial culture. Mycopath Mycol Appl 41, 287-292.

Staugaard, P., Samson, R. A. \& van der Horst, M. I. (1990). Variation in Penicillium and Aspergillus conidia in relation to preparatory techniques for scanning electron and light microscopy. In Modern Concepts in Penicillium and Aspergillus Classification, vol. 185, pp. 39-48. Edited by R. A. Samson \& J. I. Pitt. New York: Plenum Press.

Sztejnberg, A., Doron-Shloush, S. \& Gerson, U. (1997). The biology of the acaropathogenic fungus Hirsutella kirchneri. Biocontrol Sci Technol 7, 577-590.

Traquair, J. A., Shaw, L. A. \& Jarvis, W. R. (1988). New species of Stephanoascus with Sporothrix anamorphs. Can J Bot 66, 926-933.

Van der Geest, L. P. S., Elliot, S. L., Breeuwer, J. A. J. \& Beerling, E. A. M. (2000). Diseases of mites. Exp Appl Acarol 24, 497-560.

Weidenbörner, M., Uziel, A., Hamacher, J., Hindorf, H. \& Weltzien, H. C. (1989). A preparation method of Aspergillus spp. for scanning electron microscope. J Phytopathol 126, 1-6.

Yarrow, D. (1998). Methods for the isolation, maintenance and identification of yeasts. In The Yeasts, a Taxonomic Study, 4th edn, pp. 77-100. Edited by C. P. Kurtzman \& J. W. Fell. Amsterdam: Elsevier. 